Ks. Wincenty MYSZOR*

\title{
EWANGELIA JUDASZA - WPROWADZENIE DO STUDIUM
}

Udostępnienie koptyjskiego tekstu Ewangelii Judasza w 2006 r. przez National Geographic Society pozwoliło także ujawnić kulisy przygotowań do publikacji i historię rękopisu w zbiorze Codex Tchacos, w którym znajduje się ta Ewangelia. Zbiór ten był znany od ok. 1970 r., ale dopiero po ponad trzydziestu latach stał się dostępny dla świata nauki ${ }^{1}$. Wstępne studium tego gnostyckiego utworu z 2006 r., odwoływało się do tekstu koptyjskiego na stronie internetowej National Geographic Society ${ }^{2}$. Od tego czasu ukazało się wydanie krytyczne całego Kodeksu, choć pod tytułem najbardziej popularnego utworu - Ewangelii Judasza ${ }^{3}$. Wydanie całego Kodeksu z komentarzem przygotowali również badacze niemieccy: Hans-Gebhard Bethge i Johanna Brankaer w 2007 roku$^{4}$. Pojawiły się także kolejne niemieckie i angielskie thumaczenia, z propozycjami uzupełnień i wyjaśnień do koptyjskiego oryginału $u^{5}$ Zainteresowanie badaczy wczesnego chrześcijaństwa Ewangelia Judasza przeniosło się także na tematykę kongresów i naukowych dyskusji ${ }^{6}$. Stan

${ }^{*}$ Ks. prof. dr hab. Wincenty Myszor - emerytowany pracownik Wydziału Teologicznego na Uniwersytecie Śląskim w Katowicach; e-mail: wincenty2myszor@onet.pl.

${ }^{1}$ Por. Ewangelia Judasza, wstęp, thumaczenie z koptyjskiego i komentarz W. Myszor, SACh SN 3, Katowice 2006, 9-14; zob. także G. Lüdemann, Das Judas-Evangelium und das Evangelium nach Maria. Zwei gnostische Schriften aus der Frühzeit des Christentums, Stuttgart 2006.

${ }^{2}$ Por. http://www.nationalgeographic.com/lostgospel/_pdf/GospelofJudas.pdf.

${ }^{3}$ Por. The Gospel of Judas, together with the Letter of Peter to Philip, James, and a Book of Allogenes from Codex Tchacos. Critical Edition, Coptic text ed. by R. Kasser - G. Wurst, Introductions, Translations, and Notes by R. Kasser-M. Meyer - G. Wurst - F. Gaudard, Washington 2007.

${ }^{4}$ Por. Codex Tchacos. Texte und Analysen, ed. J. Brankaer - H.G. Bethge, Berlin 2007, 261-372.

${ }^{5}$ Por. P. Nagel, Das Evangelium des Judas, ZNW 98 (2007) 213-276; tenże, Das Evangelium des Judas - zwei Jahre später, ZNW 100 (2009) 101-138; U.K. Plisch, Was nicht in der Bibel steht. Apokryphe Schriften des frühen Christentum, Stuttgart 2006, 165-177; The Gospel of Judas, w: The Nag Hammadi Scriptures. The International Edition, ed. M. Meyer, New York 2007, 755-769.

${ }^{6}$ Por. The Gospel of Judas in Context: Proceedings of the First International Conference on the Gospel of Judas (Paris, Sorbonne, October $27^{\text {th }}-28^{\text {th }}$ 2006), ed. M. Scopello, Leiden 2008; The Codex Judas Papers: Proceedings ot the International Congress on the Tchacos Codex (Rice University, Houston, Texas, March $13^{\text {th }}-16^{\text {th }}$ 2008), ed. A.D. DeConick, Nag Hammadi and Manichaean Studies 71, Leiden - Boston 2009. Najwięcej nowego tekstu koptyjskiego i uzupełnienia brakujących stron przyniosła publikacja internetowa Uniwersytetu Chapmann (prof. Marvin Meyer), z której skorzystałem tylko dla przetłumaczenia na język polski odpowiednich fragmentów, bez ambicji 
badań na koniec 2010 r. ośmielił mnie do przygotowania nowego polskiego thumaczenia.

Ewangelię Judasza można zaliczyć do grupy pism gnostyckich znanych już od wielu lat jako znaczący zbiór wchodzący w skład koptyjskiej biblioteki z Nag Hammadi ${ }^{7}$. Pierwsze przypuszczenia, że jest to utwór setiański, zdają się potwierdzać w dalszych badaniach ${ }^{8}$. Setiański charakter widoczny jest niezależnie od mitologicznego fragmentu, to znaczy pouczającej mowy Jezusa ${ }^{9}$, która może być cytatem z innego pisma setiańskiego. Na obecność gnostycko-setiańskiej mitologii i teologii w Ewangelii Judasza wskazują także takie elementy, jak wątek ,wybranego pokolenia" ${ }^{10}$. Teologicznym i mitologicznym elementem setiańskiej wersji gnozy jest postać Barbelo, tajemnicze, żeńskie imię nadawane istocie w boskiej sferze:

„I rzekł mu - Jezusowi - Judasz: Wiem, kim jesteś i z jakiego wyszedłeś miejsca. Wyszedłeś z eonu Nieśmiertelnej Barbelo i od tego, który cię wysłał"11.

Pierwszym ,gnostykiem” z pokolenia wybranego był biblijny Set, syn Adama i Ewy, który w Ewangelii Judasza jest nazwany „Chrystusem”' ${ }^{2}$. Te szczegóły systemu setiańskiego wydają się wskazywać na pokrewieństwa z setiańską teologią w takich utworach z Nag Hammadi, jak Apokryf Jana, Hipostaza archontów, Ewangelia Egipcjan, Apokalipsa Adama (wymieniam je przykładowo) ${ }^{13}$. Niektóre studia wskazują także na związki z innymi kierunkami gnostyckimi, na przykład z nauką Bazylidesa ${ }^{14}$. Pojawiają się także wątpliwości w sprawie

wydania krytycznego tekstu koptyjskiego. Odkryte fragmenty są również dostępnena stronie internetowej Wydziału Teologicznego w Augsburgu. Strony te przedstawił Gregor Wurst (Preliminary Report on New Fragments of Codex Tchacos) w pierwszym tomie nowego czasopisma „Early Christianity" 1 (2010) 282-294. Nowa edycja tekstu koptyjskiego Ewangelii Judasza ukazała się w pracy L. Jenott, The Gospel of Judas, Tübingen 2011.

${ }^{7}$ Związek z tekstami z Nag Hammadi całego Kodeksu Tchacos potwierdzają dublety pism: List Piotra do Filipa; (Pierwsza) Apokalipsa Jakuba i Allogenes, por. Logan, The Tchacos Codex: Another Documents of the Gnostics?, w: The Codex Judas Papers, s. 4 i 20-21. Chodzi także o teksty zredagowane w tej samej wersji językowej (koptyjskiej), zob. N. Bosson, L'Evangile de Judas: notes linguistiques et stylistiques, w: The Gospel of Judas in Context, s. 22: „un texte comme L'Evangile de Judas n'apparait guère différent de ce qui est mis en oeuvre dans des nombreux de Nag Hammadi”.

${ }^{8}$ Por. W. Myszor, Ewangelia Judasza - wprowadzenie, SACh SN 3, 27-31; zob. także P. Nagel, Erwägungen zur Herkunft des Judasevangeliums, ZNW 101 (2010) 113.

${ }^{9}$ Por. Evangelium Iudae, p. 47, 3 - 53, 7, thum. Myszor, SACh SN 3, 58-61.

${ }^{10}$ Por. tamże, p. 36, 9 i 17; tamże, p. 37, 6 i 10; tamże, p. 40, 6; tamże, p. 44, 16; tamże, p. 46, 18.

${ }^{11}$ Por. tamże, p. 35, 15-19, SACh SN 3, 54 oraz nota 11.

${ }^{12}$ Por. Evangelium Iudae, p. 52, 5-6, SACh SN 3, 48.

${ }^{13}$ Por. Myszor, Ewangelia Judasza - wprowadzenie, SACh SN 3, 25-31. W tym systemie u szczytu boskiego bytu pozostaje trójca: Pra-Ojciec, Barbelo i Autogenes oraz stale pojawiające się wyobrażenie o czterech świetlistych eonach („Oświecicieli”) Autogenesa. Do setiańskiego systemu należy nauka o czterech periodach historii zbawienia i o potrójnym przyjściu zbawiciela.

${ }^{14}$ Por. J.D. Dubois, L'Evangile de Judas et la tradition basilidienne, w: The Gospel of Judas in Context, s. 146-154. 
„autentyczności” systemu setiańskiego w Ewangelii Judasza. Zgodnie z teorią setiańskiego gnostycyzmu (zrekonstruowanego przez Hansa Martina Schenkego) setianizm był gnozą niechrześcijańską. Tymczasem w Ewangelii Judasza, w „setianizmie” tego utworu, pojawiają się wyraźne wątki z ewangelii kanonicznych. Wątpliwości co do „czystości” wątku setiańskiego Ewangelii Judasza pojawiają się także wśród krytyków teorii H.M. Schenkego ${ }^{15}$, teorii o istnieniu i treści setiańskiej gnozy ${ }^{16}$. Wyraźne wątki nowotestamentalne wskazują albo na redakcję chrześcijańską, późniejszą w stosunku do jakiegoś wcześniej istniejącego tekstu setiańskiego, albo - co jest bardziej prawdopodobne - na powstanie Ewangelii Judasza jako chrześcijańskiego apokryfu w wersji setiańskiej ${ }^{17}$. John D. Turner ukazał setiańską treść Ewangelii Judasza, ale jednocześnie jej ,sekciarskie” treści wobec setianizmu innych gnostyckich utworów ${ }^{18}$. Jego zdaniem, tylko idea „wybranego pokolenia” jest autentycznie setiańska. Apostołowie, także Judasz, jako „trzynasty apostoł”, reprezentujący chrześcijaństwo w Ewangelii Judasza, mają wprawdzie negatywną konotację, ale są chrześcijańskiego pochodzenia. Być może - według Turnera - Ewangelia Judasza $\mathrm{w}$ świetle notatki Ireneusza ${ }^{19}$ zawiera inny gnostycki system. Turner nazwał go ,proto-setianizmem ${ }^{20}$. System ten wydaje się tożsamy z tym, jaki dotąd nazywamy barbelognostyckim. W związku z tym Turner sytuuje powstanie Ewangelii Judasza (w wersji oryginalnej, greckiej!) na koniec II wieku. O takiej datacji przesądza jednak wzmianka Ireneusza o Ewangelii Judasza ${ }^{21}$, jeśli ją zrozumiemy jako wzmiankę o konkretnym tekście, czyli o obecnie znanej

${ }^{15}$ Por. H.M. Schenke, The Phenomenon and Significance of Gnostic Sethianism, w: The Rediscovery of Gnosticim, II: Sethian Gnosticism, ed. B. Layton, Leiden 1978, 588-616.

${ }^{16}$ Por. G. Luttikhuizen, Sethianer?, ZACh 13 (2009) 80-83. Autor nawiązał tu do swojego opracowania: Gnostic Revisions of Genesis Stories and Early Jesus Tradition, Nag Hammadi and Manichaean Studies 58, Leiden 2006.

${ }^{17}$ Setianizm Ewangelii Judasza umacniałby tym samym twierdzenie przeciwników setianizmu jako gnozy przed- lub pozachrześcijańskiej i dostarczałby dowodu na istnienie setianizmu jako gnozy chrześcijańskiej, por. Luttikhuizen, Sethianer?, s. 85: „Aus mehreren Gründen sollten wir die Auffassung, daß die Lehre des Apokryphon des Johannes und anderer angeblich sethianischer Schriften wesentlich vorchristlichjüdisch sind, verabschieden".

${ }^{18}$ Por. J. Turner, The Place of the „Gospel of Judas” in Sethian Tradition. w: The Gospel of Judas in Context, s. 187-237.

${ }^{19}$ Por. Irenaeus, Adversus haereses I 29, ed. A. Rousseau - L. Doutreleau, SCh 264, Paris 1979, 358-364.

${ }^{20}$ Por. Turner, The Place of the , Gospel of Judas”, s. 224.

${ }^{21}$ Por. Irenaeus, Adversus haereses I 31, 1, SCh 264, 386, tłum. Myszor, SACh SN 3, 81 : „Inni (gnostycy) znów wygłaszają naukę, że Kain pochodzi od wyższej władzy. Przyznają się do Ezawa, Kore i Sodomitów, i wszystkich ich uznają za swoich krewnych. Dlatego sądzą, że stwórca uznaje ich za wrogów, chociaż żaden z nich zła od niego nie doznał. Sophia natomiast wzięła od nich to, co jest jej własnością. I to, jak nauczają, znał także dokładnie zdrajca, Judasz. On bowiem jako jedyny spośród wszystkich (uczniów), poznał prawdę i spełnił tajemnicę wydania. Przez niego zostały rozwiązane - jak mówią - wszystkie sprawy ziemskie i niebieskie. W takim sensie wykładają dzieło o takiej treści i nazywają to ewangelia Judasza". 
nam Ewangelii Judasza ${ }^{22}$. Grecka wersja Ewangelii Judasza między końcem II a początkiem IV w. ${ }^{23}$, mogła być poddana nowej redakcji. Wtedy, być może, została uzupełniona elementami chrześcijańskimi i setiańskimi. Marvin Meyer, podobnie jak Turner, sądzi, że Ewangelia Judasza może być świadectwem „wczesnego" (młodego) setianizmu²4. Setianizm Ewangelii Judasza został w III w. ,przeredagowany”. W tym czasie także, zdaniem Turnera, w „,nowej” redakcji Ewangelii Judasza poddano krytyce „kościelne” instytucje chrześcijańskie, chrzest i ofiarę (eucharystię). Ewangelia Judasza stała się bliska Apokalipsy Adama ${ }^{25}$ i Potrójnej Protennoii ${ }^{26}$. W tym czasie - jak sądzi Turner - przekaz gnozy setiańskiej odłączył się od chrześcijańskiego nurtu i zbliżył się do pogańskiego platonizmu. Wersję platońsko-setiańską gnostycyzmu potwierdzają, według Turnera, traktaty z Nag Hammadi: Zostrianos ${ }^{27}$, Alloge$n_{e s}{ }^{28}$, Trzy stele Seta $^{29}$ oraz powstały jeszcze później Marsanes ${ }^{30}$. Wzmianka o Ewangelii Judasza u Ireneusza interpretowana jest także jako wskazówka utworu napisanego przez tak zwanych „,kainitów”. Nazwa tej grupy gnostyków miała wskazywać na biblijnego Kaina. Negatywna ocena tej biblijnej postaci wzbudza oczywiście podejrzenie, że opinia o istnieniu kainitów zrodziła się wśród polemistów antygnostyckich. Do notatki Ireneusza o „kainitach” jako grupie setian, wśród których mogła powstać Ewangelia Judasza, nawiązała April DeConick. Przeanalizowała wzmianki o „kainitach” u Epifaniusza oraz u Pseudo-Tertuliana ${ }^{31}$ i przedstawiła swoją opinię na temat autorstwa Ewangelii Judasza oraz jej związku z gnostykami, nazwanymi „kainitami”. Ireneusz mówił o Ewangelii Judasza w tym samym akapicie ${ }^{32}$, w którym wspomniał

${ }^{22}$ Na podstawie wzmianki o Kainie przypisano Ewangelię Judasza gnostyckiej sekcie kainitów. Ireneusz twierdzi jednak, że zwolennicy gnostyckiego systemu, jaki wyłożył w Adversus haereses I 29-31 (SCh 264, 358-390) zaliczyli Kaina, synów Korego i Sodomitów, do „wybranego pokolenia" Seta. Gnostycka sekta Kainitów chyba nie istniała. O notatce źródłowej na temat Ewangelii Judasza u Ireneusza por. także: J. van Oort, Irenaeus on the „Gospel of Judas”. An Analysis of the Evidence in Context, w: The Codex Judas Papers, s. 43-56.

${ }^{23}$ Uwagi o datacji powstania Kodeksu Tchacos por. Myszor, Ewangelia Judasza - wprowadzenie, SACh SN 3, 13.

${ }^{24}$ Por. M. Meyer, When the Sethians were Young, w: The Codex Judas Papers, s. 57-73. Interpretację Judasza jako reprezentanta upadłej i zbawczej Sophia zob. w rozdziale pt. Judas and Sophia in the Second Century (tamże, s. 66-73). O istnieniu setian w II wieku (niezależnie od źródła informacji u Ireneusza) mówi: G. Schenke-Robinson, The Gospel of Judas. Its Protagonist, its Composition, and its Community, w: The Codex Judas Papers, s. 90, nota 69.

${ }^{25}$ Por. NHC V 5.

${ }^{26}$ Por. NHC XIII 1. Zob. J.D. Turner, The sethian Myth in the „, Gospel of Judas”. Soteriology or Demonology? w: The Codex Judas Papers, s. 130nn.

${ }^{27}$ Por. NHC VIII 1.

${ }^{28}$ Por. NHC XI 3.

${ }^{29}$ Por. NHC VII 5.

${ }^{30}$ Por. NHC X. Por. Turner, The sethian Myth in the „Gospel of Judas”, s. 133.

${ }^{31}$ Por. Ps-Tertullianus, Adversus omnes haereses 2, 5-9, CSEL 2, 1404, SACh SN 3, 86-87.

${ }^{32}$ Por. Irenaeus, Adversus haereses I 31, 1, SCh 264, 386, SACh SN 3, 80-81. 
o Kainie jako biblijnej postaci zależnej od „wyższej władzy”, czyli od Boga Starego Testamentu, którego na innym miejscu nazywa demiurgiem, Jaldabaothem. Ireneusz nie twierdził, że „kainici” zredagowali Ewangelię Judasza, ale że gnostycy (barbelognostycy? setianie) używali jej i tak interpretowali. Owych domniemanych setian nazywa Ireneusz „barbelognostykami”33. Naukę setian (barbelognostyków) znał Ireneusz bardzo dobrze i autorstwo Ewangelii Juda$s z a$ przypisał raczej setianom, a nie „kainitom”, których nie znał jako osobnej grupy gnostyków. O herezji kainitów wyraźnie mówił natomiast Pseudo-Tertulian. Zwolennicy tego odłamu gnozy, według Pseudo-Tertuliana, czcili także Judasza. Tym gnostykom Pseudo-Tertulian jednak nie przypisał autorstwa Ewangelii Judasza. Mógł jednak połączyć wzmiankę o Judaszu z przeciwnikami kościelnego chrztu „, w wody” w Kartaginie. Krytykę kościelnego chrztu znajdziemy w Ewangelii Judasza ${ }^{34}$, ale także w innych źródlach setiańskich: Świadectwo prawdy is i Parafraza Sema ${ }^{36}$. Ewangelię Judasza przypisał wyraźnie kainitom dopiero Epifaniusz z Salaminy, który odwołał się do wzmianki u Ireneusza, bo sam tekstu tej Ewangelii nie zna1 ${ }^{37}$.

Jeśli autorstwo Ewangelia Judasza należy przypisać chrześcijańskim setianom, co w świetle dotychczasowych badań wydaje się najbardziej prawdopodobne, to interesujące staje się pytanie, o jaki rodzaj chrześcijaństwa tu chodzi. Według Ewangelii Judasza wyjątkową postacią jest Jezus. To Jezus, podobnie jak w Nowym Testamencie, „objawił się na ziemi, czynił znaki i cuda dla zbawienia ludzkości” ${ }^{38}$. Powołał „Dwunastu uczniów”, których wprowadził w tajemnice zbawienia ${ }^{39}$, w „tajemnice królestwa"40. Ewangelia Judasza przedstawia Jezusa w nawiązaniu do tradycji nowotestamentalnej, do nauki Wielkiego Kościoła. Włącza nawet wątek „wydania Jezusa" na śmierć ${ }^{1}$, jednak nie nadaje śmierci Jesusa zbawczego znaczenia, przeciwnie, poddaje ją gnostyckiej interpretacji ${ }^{22}$. Ujęcie postaci Jezusa stanowi także istotną część gnostyckiego systemu w Ewangelii Judasza.

${ }^{33}$ Por. tamże I 29, 1, SCh 264, 358, SACh SN 3, 64-65.

${ }^{34}$ Por. Evangelium Iudae, p. 55, 21 - 56, 1.

${ }^{35}$ Por. Testimonium Veritatis, NHC IX 3.

${ }^{36}$ Por. Paraphrasis Sem, NHC VII 1.

${ }^{37}$ Por. A.D. DeConick, After the „, Gospel of Judas”: Reassesing what we have known to be True about Cain and Judas, w: In Search of Truth: Augustine, Manichaeism and other Gnosticism. Studies for Johannes van Oort at Sixty, ed. J. van den Berg - A. Kotzé - T. Nicklas - M. Scopello, Leiden 2011, 658.

${ }^{38}$ Evangelium Iudae, p. 33, 6-9, SACh SN 3, 37.

${ }^{39}$ Por. tamże, p. 33, 15-18, SACh SN 3, 37.

${ }^{40}$ Por. tamże, p. 35, 25 i p. 45, 26, SACh SN 3, 39 i 44.

${ }^{41}$ Por. tamże, p. 56, 7. 20; p. 58, 9-26.

${ }^{42}$ Por. W. Myszor, Jezus w „Ewangelii Judasza”, w: tenże, Gnostycyzm i teologia Ireneusza z Lyonu. Zagadnienia wybrane, SACh SN 11, Katowice 2010, 115-119; zob. także: J. Brankaer, Whose Savior. Salvation, Damnation and the Race of Adam in the Gospel of Judas, w: The Codex Judas Papers, s. 391-395. 
Jezus pochodzi z wyższego „eonu”. Został posłany przez Boga, którego imienia nie można wymawiać ${ }^{43}$. Nie jest nim jednak ten Bóg, któremu kapłani (apostołowie) składają ofiary. Apostołowie wprawdzie sądzą inaczej - „Nauczycielu, ty jesteś posłanym Synem naszego Boga”44, jednak Jezus nie przyznaje się do Boga chrześcijańskich apostołów. Odpowiada apostołom nazywając Boga, któremu składali dziękczynienie, „waszym Bogiem” („Co zrobiliście, uczyniliście nie z waszej woli, lecz żeby w tym wasz Bóg był uwielbiony" $)^{45}$. Jezus ujawnia jednak związek z Bogiem, którego czczą apostołowie. Gdy wypowiada się o ofiarach składanych Saklasowi, mówi także o swojej śmierci:

„Tego, który mnie niesie, jutro zamęczą. Ale zaprawdę mówię wam: nie ma żadnej takiej ludzkiej ręki, która jako śmiertelna będzie mogła wobec mnie zgrzeszyć $[\ldots]$ Człowieka bowiem, który mnie nosi, ty ofiarujesz" ${ }^{\prime 46}$.

Cytowany tu fragment podaję $\mathrm{z}$ uzupełnieniami po odkryciu nowych stron rękopisu. Judasz wydał ,człowieka, który nosił” Jezusa, a więc tego, który został ofiarowany na śmierć (,jutro mnie zamęczą"), ofiarowany Bogu, którego czcili apostołowie. Śmierć Jezusa przedstawiono jako ofiarę, choć brak w Ewangelii Judasza opisu męki i śmierci Jezusa, jak w ewangeliach kanonicznych. Śmierć człowieka, „który nosił Jezusa” została przedstawiona na planie dualistycznej chrystologii gnostyków ${ }^{47}$. Chrystologia Ewangelii Juda$s z a$, a więc postać Jezusa i jego dzieło zbawcze, wskazuje na gnostycką teologię, dokładnie, na chrystologię chrześcijańsko-gnostycką.

Najbardziej intrygującym tematem Ewangelii Judasza jest krytyka chrztu i eucharystii. Dzięki uzyskaniu dostępu do nieznanych dotąd stron Ewangelii badacze podjęli porównywanie terminologii sakramentalnej Nowego Testamentu, w pismach z II wieku oraz w Ewangelii Judasza. Autor Ewangelii używa rozpowszechnionych ofiarnych metafor, żeby zaatakować nauczanie i życie Kościoła większości chrześcijan. Cytat, który dotyczy akceptacji ofiary przez Boga ${ }^{48}$, można zrozumieć jako gnostycką aluzję, że zaatakowana grupa, chrześcijanie Kościoła, pojęli, że w nich spełniało się proroctwo Malachiasza (Ml 1, 10-14); tak interpretowali je Justyn Męczennik, Ireneusz i Tertulian. Ewangelia Judasza przekształca to w oskarżenie, że Kościół większości przez

${ }^{43}$ Por. Evangelium Iudae, p. 35, 18-22, SACh SN 3, 39.

${ }^{44}$ Tamże, p. 34, 12-13, SACh SN 3, 38.

${ }^{45}$ Tamże, p. 34, 8-11, SACh SN 3, 38. Podobnie tamże, p. 34, 25-26, tłum własne: „To wasz Bóg, który jest wśród was i jego aniołowie. Bogiem, któremu składają ofiary jest Saklas”; por. rekonstrukcję tekstu (Codex Tchacos. Texte und Analysen), tamże, p. 56, 14.

${ }^{46}$ Evangelium Iudae, p. 56, 7-21, tłum. własne; por. Nagel, Das Evangelium des Judas - zwei Jahre später, s. 134.

${ }^{47}$ Podobnie jak w innych tekstach gnostyckich, np. w Drugiej nauce Wielkiego Seta i Apokalipsie Piotra z biblioteki z Nag Hammadi, por. W. Myszor, Chrystologia gnostyków: podstawowe problemy, w: tenże, Gnostycyzm i teologia Ireneusza z Lyonu, s. 106-114.

${ }^{48}$ Evangelium Iudae, p. 40, 18-23, SACh SN 3, 42. 
takie „ofiary” „zabija” swych ludzi; ofiary składane są fałszywemu Bogu, Saklasowi władającemu światem archonta ${ }^{49}$.

Treść odzyskanych ostatnio stron Ewangelii Judasza potwierdza dotychczasowe ustalenia. Największe fragmenty odzyskano na stronach: p. 41, 9-24; p. 42, 9-26; p. 55, 5-12; p. 56, 5-11; p. 57, 4-8; p. 58, 4-8. Cały szereg drobniejszych uzupełnień i rekonstrukcji dotyczy także stron: p. 37, 10-22; p. 38, 10-23; p. 53, 1-10; p. 54, 1-9. W niniejszym artykule zajmę się tylko sześcioma stronami, czyli tymi, które zawierają większe partie tekstu i które wnoszą do naszej analizy treściowej więcej ciekawych wątków. Całość rekonstrukcji znajduje się w nowym polskim tłumaczeniu (nie mam dostępu do facsimile nowych stron, poza obrazkami w Internecie; a przede wszystkim nie mam takiej wiedzy paleograficznej, jaką mają zachodni badacze, dlatego czekam na ich publikacje).

Pierwszy obszerniejszy fragment z p. 41:

„Niech więc staną się [pustymi] dla was, [niech schodzą ku] swej [zagładzie], niech się (te sprawy) staną jawne [dla was]" ${ }^{\text {50 }}$. (10) Jego uczniowie zaś rzekli: „Panie, oczyść nas [od ...] popełnialiśmy to z powodu blędnej myśli aniołów” ${ }^{51}$. Jezus im powiedzial: „Niemożliwe jest [...] (15) [...] ... [ani] nie jest możliwe, aby źródło wody ugasiło [płomień] całego zamieszkałego świata [ani] strumień w jakimś [mieście] nie może (20) nasycić wszystkich pokoleń, ale tylko to (pokolenie) wielkie, dla którego jest przeznaczony. I lampa jedna nie może oświetlić wszystkich eonów za wyjątkiem drugiego pokolenia ${ }^{52}(25)$ ani piekarz nie może wyżywić stworzenia $(42,1)$, całego (które jest) [pod niebem]".

Nowe wiersze, odzyskane dla p. 41 uzupełniają dialog Jezusa i apostołów. Jezus zachęca uczniów do poznania nowej rzeczywistości duchowej i odrzucenia pozorów, uczniowie przyznają, że popełniali przestępstwa pod wpływem władzy aniołów (czyli archontów) rządzących światem. Dalsza wypowiedź

${ }^{49}$ Por. J.K. Schwartz, Die Kultpolemik im „Evangelium des Judas”, „Early Christianity” 3 (2012) 59-84.

${ }^{50}$ W wierszach z Evangelium Iudae, p. 41, 7-9, idę za: M. Meyer, The Tchakos Fragments of the Gospel of Judas. Paper presented at the Society of Biblical Literature Annual Meeting (New Orleans, November 2009) (online: http://www.chapman.edu/wilkinson/religious-studies/_files/marv-meyer/

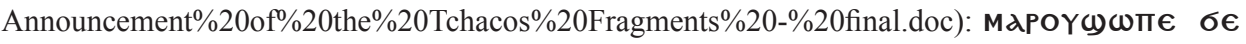

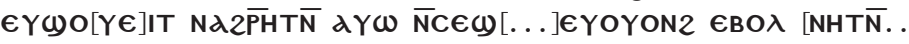

${ }^{51}$ W wierszach z Evangelium Iudae, p. 41, 9-13, idę za M. Meyer, The Tchakos Fragments of the

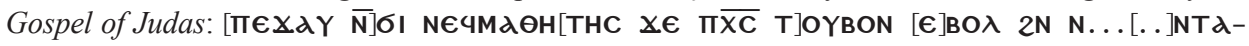

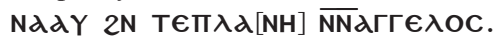

${ }^{52} \mathrm{~W}$ wierszach z Evangelium Iudae, p. 41, 13-24, idę za M. Meyer, The Tchakos Fragments of

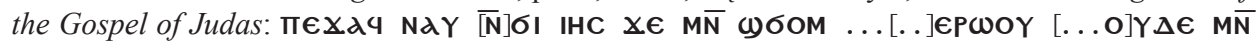

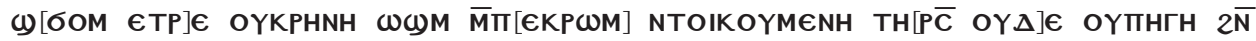

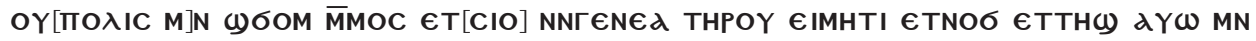

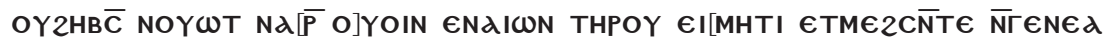


Jezusa odwołuje się do symboliki ognia, wody i lampy. Symbole te odnoszą się do życia doczesnego, a jednocześnie wskazują na zbawienie zapewnione tylko dla wybranych z pokolenia Seta. Interesująca w tym fragmencie jest natomiast wzmianka o „drugim” pokoleniu, dla którego doczesne symbole wybrania mogą mieć jakieś względne znaczenie.

Fragment z następnej strony p. 43:

„Powiedział więc im (Jezus): Zaprzestańcie walczyć ze mną. Każdy z was ma swoją gwiazdę i każda [...] z gwiazd (10) brać (?) [... to], co do niego należy. [... Ja zaś] nie zostałem posłany do pokolenia zniszczalnego, lecz do pokolenia, które jest mocne i niezniszczalne. Tamto bowiem pokolenie (15) nie jest przeciwnikiem, aby nad nim panować, ani jednym wśród gwiazd. Zaprawdę powiadam [wam], nadejdzie szybko słup (20) ognia i tamto pokolenie nie będzie poruszone [... ani] gwiazda. I gdy Jezus to powiedzial, odszedł i [wziął] Judasza Iskariotę ze sobą. (25) Powiedzial (wówczas to) do niego: Woda, która [... z] wysokiej góry ${ }^{53}[\ldots]$ ".

Fragment wypowiedzi Jezusa podkreśla wyjątkowość pokolenia Seta („mocne” i „niezniszczalne”); tylko do niego został Jezus posłany. Jezus zapowiada zniszczenie ,tamtego pokolenia” jakiejś innej grupy ludzi, do których nie został posłany. Pod koniec fragmentu tekst wyróżnia Judasza Iskariotę: „Jezus odszedł (od uczniów) i zabrał Judasza ze sobą".

Fragment ze strony p. 55:

„Wtedy będą (25) popełniać cudzołóstwa w imię moje i zabijać będą swoich synów $(55,1)$ [popełniać będą] zło i [...] [...] będą spać $\mathbf{z}$ mężczyznami] [... aż] przyjdzie [...] [dwanaście] wśród [...] eonów (5) prowadzą swe pokolenia i przedstawią je Saklasowi ${ }^{54}$. A potem nadchodzi [Izra]el wyprowadzając dwanaście plemion Izraela [...], (10) aby służyły Saklasowi wszystkie pokolenia, grzesząc $\mathrm{w}$ moim imieniu ${ }^{55}$. A twoja gwiazda będzie panować nad trzynastym eonem. Następnie Jezus się roześmiał”.

${ }^{53} \mathrm{~W}$ wierszach z Evangelium Iudae, p. 41, 9-26, idę za M. Meyer, The Tchakos Fragments of the

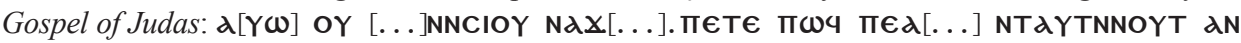

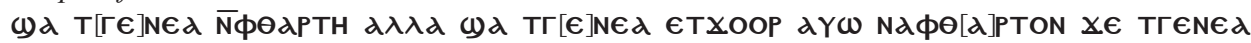

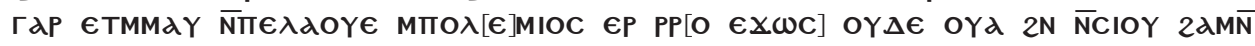

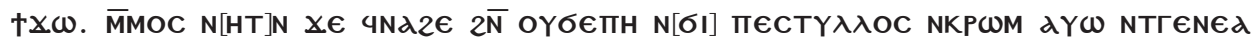

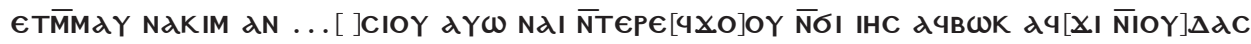

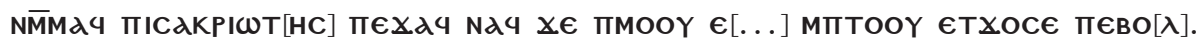

${ }^{54}$ Na podstawie Codex Tchacos. Texte und Analysen, Berlin 2007 i M. Meyer, The Tchakos Fragments of the Gospel of Judas, rekonstruuję wiersze z Evangelium Iudae, p. 55, 1-6: dү山

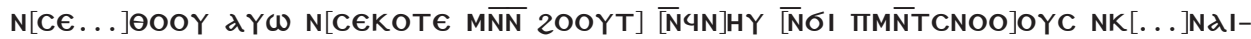

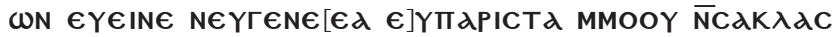

${ }^{55}$ Na podstawie M. Meyer, The Tchakos Fragments of the Gospel of Judas rekonstruuję wiersze

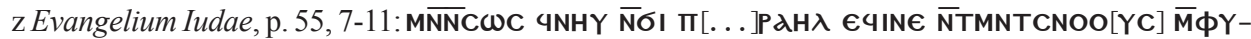


Przywrócony fragment tekstu potwierdza podobną wypowiedź we wcześniejszym wydaniu. Najpierw uczniowie przedstawiają wizję ${ }^{56}$. Na pytanie Jezusa, o jakich kapłanów chodzi, uczniowie odpowiadają:

„Oni zaś [rzekli: „Jedni] byli co (15) poszczą przez dwa tygodnie, [inni] zaś ofiarują swoje dzieci, inni zaś swoje żony błogosławiąc i poniżając się wzajemnie. (20) Jeszcze inni spali z mężczyznami, inni trudzili się zabijaniem, jeszcze inni dopuszczali się mnóstwa grzechów i bezprawia. Mężczyźni zaś, którzy stali (25) przy ołtarzu, wzywali twoje imię"57.

Wreszcie Jezus wyjaśni wizję apostołów:

„Wy jesteście tymi, którzy podejmą służbę (20) przy ołtarzu. A więc wy zobaczyliście tego, który jest Bogiem i któremu służycie. A Dwunastu mężczyzn, których zobaczyliście, to wy (25) właśnie, a trzoda tych, których przyprowadzają do ofiary to ci, których widzieliście. Jest to tłum, który wprowadziliście w błąd $(40,1)$ przy tamtym ołtarzu, bo stanie (tu) [władca tego świata] ${ }^{58}$. $\mathrm{W}$ ten oto sposób będzie korzystał z mojego imienia, zaś w gotowości czekać będą pobożne pokolenia. Następnie inny człowiek przedstawi ${ }^{59}$ rozpustnika, a inny (10) przedstawi zabójców dzieci, a inny takich, co śpią z mężczyznami, (ale także takich), co poszczą ${ }^{60}$, a inny będzie oczyszczał od bezprawia i błędu (15). I ci mówią (o sobie): my jesteśmy równi aniołom (por. Łk 20,36)".

Odzyskany tekst potwierdza krytykę kapłanów, ,dwunastu mężczyzn przy ołtarzu”, którzy składają ofiary Saklasowi, czyli Bogu-stwórcy. W dyskusjach naukowych, jak to na wstępie wskazałem, komentatorzy wyjaśniają, że chodzi o krytykę oficjalnego Kościoła: krytykę chrztu, ofiar i poddawania się prześladowaniom. O jaką grupę setian, chrześcijańskich gnostyków tu chodzi, nie wiadomo.

Fragment z następnej strony p. 56:

„Rzekł Jezus: „Zaprawdę (25) mówię [ci], to obmycie $(56,1)$ [które przyjęli] w imię moje [stanie się (dla nich) hańbą ${ }^{61}[\ldots]$ (5) zniszczy cale pokolenie

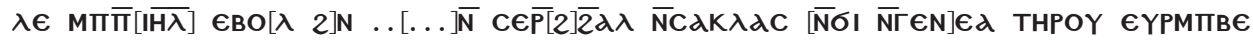
[ON 2]N TPAN

${ }^{56}$ Por. Evangelium Iudae, p. 38, 1-11, tłum. własne: „Oni zaś powiedzieli: «Widzieliśmy wielki dom i był w nim wielki ołtarz oraz dwunastu mężczyzn, o których mówimy, że są to (5) kapłani, oraz pewne Imię. Jakiś thum trwał cierpliwie [przy tamtym ołtarzu] aż kapłani będą gotowi (10), by podjąć (swoją) służbę. My także trwaliśmy cierpliwie»”.

${ }^{57}$ Tamże, p. 38, 15-26, tłum. własne.

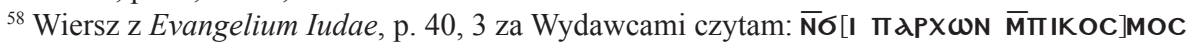
d $ү \omega$; por. J 12, 31; 14, 30; 16, 11.

${ }^{59}$ Kopt. паPICTd.

${ }^{60}$ Por. Evangelium Thomae 27.

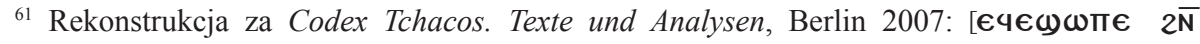
TMN̄T גTIMH].
} 
Adama ziemskiego. A tego, który mnie niesie, jutro zamęczą. (Ale) zaprawdę mówię wam; nie ma żadnej (10) (takiej) ludzkiej ręki, która jako śmiertelna będzie mogła wobec mnie zgrzeszyć" ${ }^{62}$.

Fragment potwierdza inne wypowiedzi poświęcone eschatologii: zginie pokolenie „Adama ziemskiego”, w nim także Jezus-ziemski (drugi Adam?); „tego, który mnie niesie, jutro zamęczą" - to oczywiście nawiązanie do przedwielkanocnej zapowiedzi męki Chrystusa w ewangeliach kanonicznych. Tekst uzupełnia znany już wcześniej z Ewangelii Judasza motyw ,zdrady” (p. 56, 19-20: „człowieka, który mnie nosi, ty ofiarujesz” oraz p. 58, 24-26: „Judasz wziął pieniądze i wydał go im").

Strona p. 57 - przywrócono tylko cztery wiersze:

„Zaprawdę [mówię ci, twoje] ostatnie [... stanie się], i ten [, który] [...] stanie się [...] . [...] na sługą.] eonu a [...] królowie stali się słabymi i pokolenia aniołów jęknęły. To, co złe [...]......] Archont (10) zostaje zniszczony. I wtedy podniosą się postacie wielkiego pokolenia Adama, gdyż ponad niebem i ziemią i aniołami istnieje pokolenie $\mathrm{z}$ eonu".

Tym razem odzyskane wiersze niewiele wnoszą. Wydaje się, że chodzi o wypowiedź Jezusa o treści eschatologicznej: zbawienie pokolenia Adama, natomiast zniszczenie pokolenia królów i aniołów eonu doczesnego.

Ze strony p. 58 - podobnie cztery wiersze:

„Judasz podniósł oczy i zobaczył świetlisty obłok i wszedł do niego ${ }^{63}$. Ci, którzy stali niżej usłyszeli (25) głos wychodzący z obłoku, który głosił: (58, 1) [..........] wielki ród. [...] obraz [...] w (5) nim" [...] Judasz przestał widzieć Jezusa [...]".

Odzyskane wiersze tekstu Ewangelii Judasza, wskazują jedynie na rozumienie już wcześniej znanych wierszy o Judaszu: „Judasz podniósł oczy i zobaczył świetlisty obłok i wszedł do niego". Podmiotem obydwu zdań wydawał się być Judasz i tak komentowano postać Judasza, trzynastego apostoła, że po otrzymaniu objawienia zobaczył chwałę bożą (,świetlisty obłok") i wszedł do tej chwały. Tymczasem zakończenie tego fragmentu odzyskanego tekstu, a zwłaszcza zdanie „Judasz przestał widzieć Jezusa”, wskazuje na zmianę podmiotu drugiego zdania „Judasz podniósł oczy, zo-

${ }^{62}$ Wiersze z Evangelium Iudae, p. 56, 4-11, za rekonstrukcją M. Meyer, The Tchakos Fragments

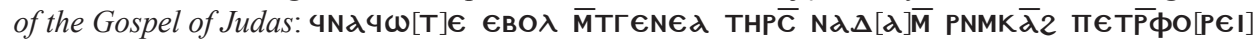

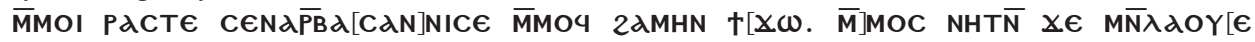

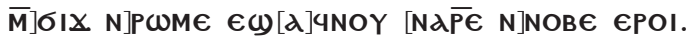

${ }^{63}$ Być może zmiana podmiotu: „I (Jezus) wszedł do niego (do obłoku)”. W świetle kontekstu

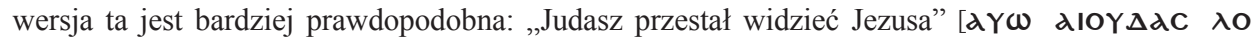
EINAY $[\epsilon] \overline{\mathrm{IHC}}]$. 
baczył świetlisty obłok i (Jezus) wszedł do niego” i logicznie dalej „Judasz przestał widzieć Jezusa".

Nowe karty Ewangelii Judasza uzupełniają tekst do tego stopnia, że utwierdzają mnie w przekonaniu, iż głównym bohaterem Ewangelii nie jest Judasz, lecz Jezus objawiający w dialogu z apostołami i Judaszem naukę o zbawieniu pokolenia gnostyków. Jezus nazwany raz Setem, a innym razem Adamem, bliższy jest tradycji nowotestamentalnej, niż to się na początku wydawało.

Ewangelia Judasza jako gnostycki apokryf wskazuje na chrześcijańską wersję gnostyckiej nauki setian. Dotąd sądzono, że setianie, w odróżnieniu od walentynian, tworzyli odłam niechrześcijańskiego gnostycyzmu. Być może Ewangelia Judasza była setiańskim pismem zredagowanym na użytek polemiki z Kościołem oficjalnym. Dalsze studia zapewne wyjaśnią bliżej genezę tej Ewangelii.

\section{THE GOSPEL OF JUDAS - INTRODUCTION TO THE STUDY}

\section{(Summary)}

The article is informing new sides of the Gospel of the Judas of the state of the research on the Coptic text of the Gospel of the Judas. He is pointing at the importance of the cover and the publication of new fragments of the Coptic text. New fragments, published after the critical edition are pointing on gnostic contents of the Gospel. He is a focal point of the Gospel gnostic Jesus, exactly Christ which the Judas is freeing giving the Jesus' body to the death.

Słowa kluczowe: chrystologia gnostyków, zdrada Judasza według gnostyków. Key words: christology of Gnostics, betrayal of the Judas according to Gnostics. 
